\title{
A 'Aliança do Pacífico’ no contexto da integração regional na América Latina
}

\author{
Ariane de Oliveira Saraiva ${ }^{1}$
}

\section{RESUMO}

O paper apresenta algumas das possíveis implicações da recente formalização da Aliança do Pacífico, voltada a assuntos econômicos e à região Ásia-Pacífico, e o que esta pode representar para o contexto político e econômico da América Latina, em especial para o Brasil. A iniciativa diferencia-se da tendência atual dos principais projetos de integração regional e sai na frente em relação aos desafios comerciais com grandes parceiros.

Palavras-chave: América Latina; Integração; Aliança do Pacífico; MERCOSUL.

Nos dias 6 e 7 de junho, ocorreu a IV Cúpula da Aliança do Pacífico, reunindo os Presidentes Sebastián Piñera do Chile, Juan Manuel Santos da Colômbia, Felipe Calderón do México e Ollanta Humala do Peru, além do Ministro das Relações Exteriores da Costa Rica e o vice Ministro das Relações Exteriores do Panamá, representando os países observadores, para ratificar o Tratado Constitutivo da Aliança do Pacífico.

A Aliança nasceu da iniciativa do ex-presidente do Peru, Alan García, em 2010. Em abril de 2011 foi assinada a "Declaração de Lima", contendo os objetivos de sua constituição, voltados à liberalização comercial entre os membros e sua maior projeção em direção à região Ásia-Pacífico. Para tanto, contará com um Grupo de Alto Nível para representar o bloco no exterior, principalmente nessa região. Além da formalização dos Tratados de Livre Comércio (TLC) de bens e serviços, objetiva-se igualmente a livre circulação de pessoas, a integração financeira e de capitais e a integração física. Em números, os países da Aliança representam, juntos, cerca de 35\% do PIB e 55\% do total das exportações da América Latina.

A principal característica em comum desses países - em especial Chile e México - é o seu grau de abertura econômica. Todos possuem acordos de livre comércio 
firmados com EUA e, além disso, Chile, México e Peru fazem parte do Foro de Cooperação Econômica Ásia Pacífico (APEC). Com a Europa, os países têm firmados os Tratados de Associação (Chile e México) ou Tratados Multipartes (Colômbia e Peru) (MALAMUD, 2012, p.3-5).

Na visão de Almeida (2012), mesmo exibindo semelhança entre os membros, a Aliança do Pacífico deve ter dificuldade para sustentar uma posição negociadora concertada, dado o desafio de coordenar interesses domésticos divergentes, correndo o risco de os países envolvidos permanecerem geograficamente isolados uns dos outros.

Entretanto, Malamud (2012) defende que, à medida que se consolide, a criação da Aliança trará consequências significativas para o processo de integração regional, em especial para os interesses brasileiros na integração sul-americana. Diante disso, alguns analistas veem a Aliança como mais um fator motivador da ampliação do MERCOSUL, através da incorporação da Venezuela, que, por sua vez, foi acelerada pelo impeachment de Fernando Lugo. A consequente suspensão do Paraguai do bloco foi levada a cabo devido ao entendimento de ter havido uma ruptura da ordem democrática e é válida até que novas eleições presidências democráticas sejam realizadas naquele país.

Enquanto a UNASUL objetiva a concertação política e o MERCOSUL enfrenta um período de paralisia, de início, conforme ressalta Malamud, a Aliança transcendeu a discussão entre América Latina e América do Sul, pela presença do México, resolvendo tal dilema pela ação. Além disso, diferencia-se por voltar a valorizar o comércio como essencial para a integração e por objetivar transcender a região. Segundo Piñera, presidente do Chile, "não se pretende rivalizar com outros tipos de acordos e alianças que existem na América Latina, é simplesmente uma maneira de avançar mais rápido e chegar mais longe em nossa integração e em nossa projeção para a Ásia-Pacífico”. Neste sentido, o desafio da Aliança se revelaria na negociação com parceiros orientais, em especial a China, para conter a predominância da exportação de produtos primários, tendência esta que acomete vários países emergentes e latino-americanos, quando se trata do intercâmbio comercial com esse país.

Vale lembrar ainda que Chile, Peru e Colômbia criaram o Mercado Integrado Latino-americano (MILA), que opera desde maio de 2011, integrando as bolsas de valores de Lima, a bolsa de comércio de Santiago e a Bolsa de Valores da Colômbia, e ao qual o México apresenta pretensões de aderir. 


\section{Referências Bibliográficas}

"Aliança do Pacífico": uma nova iniciativa que une Chile, Colômbia, México e Peru. Carta Mensal INTAL no 177, Maio 2011. Disponível em: http://idbdocs.iadb.org/wsdocs/getdocument.aspx?docnum=36387096. Acesso em 02/07/2012.

ALMEIDA, Paulo R. (2012). Pacific Alliance Faces Unique Challenges. Disponível em: http://diplomatizzando.blogspot.com.br/2012/06/alianca-do-pacifico-eintegracao.html. Acesso em: 29/06/2012.

BBC BRASIL. Bastidores de cúpula indicam pressa em ampliar o Mercosul. Disponível em: http://www.bbc.co.uk/portuguese/noticias/2012/07/120702_mercosul_bastidore s_mc.shtml. Acesso em 04/07/2012.

MALAMUD, Carlos (2012). La Alianza del Pacífico: un revulsivo para la integración regional en América Latina. ARI 46/2012. Disponível em: http://www.realinstitutoelcano.org/wps/portal/rielcano/contenido?WCM_GLOBA L_CONTEXT=/elcano/elcano_es/zonas_es/ari46-2012. Acesso em 29/06/2012. 